\title{
IZOD IMPACT TESTES IN POLYESTER MATRIX COMPOSITES REINFOCED WITH FIQUE FIBERS*
}

\author{
Maria Carolina Andrade Teles ${ }^{1}$ \\ Giulio Rodrigues Altoé2 \\ Marcos Vinícius Fonsceca Ferreira ${ }^{3}$ \\ Djalma Souza ${ }^{4}$ \\ Frederico Muylaerte Margem ${ }^{5}$ \\ Sergio Neves Monteiro ${ }^{6}$
}

\section{Resumo}

Uma fibra natural apresenta características interfaciais com matrizes poliméricas que favorecem a absorção de alta energia de impacto da estrutura compósita . Este trabalho procura avaliar a resistência ao impacto deste tipo de matriz de poliéster com reforço de fibras naturais. As fibras de Fique foram misturadas com resina de poliéster sob pressão em um molde metálico, e curada à temperatura ambiente durante 24 horas. Amostras padrões foram preparadas até $30 \%$ em volume de fibras Fique alinhadas ao longo de todo o seu comprimento, estas amostras foram então testadas com ensaio de impacto Izod do pêndulo e as superfícies de fratura examinadas por microscopia eletrônica de varredura, MEV. A resistência ao impacto aumenta substancialmente com a quantidade relativa de fibra de Fique como reforço do compósito . Isto pode ser atribuído a uma descolagem preferencial da interface fibra / matriz , o que contribui para uma elevada energia absorvida.

Palavras-chave: Compósito; Fique, Fibra, Poliéster.

\section{ENSAIOS DE IMPACTO IZOD EM COMPÓSITOS DE MATRIZ POLIÉSTER REFORÇADOS COM FIBRAS DE FIQUE}

\begin{abstract}
A natural fiber presents interfacial characteristics with polymeric matrices that favor a high impact energy absorption by the composite structure. This work attempts to evaluate the impact resistance of this type of fiber reinforcing polyester matrix. The Fique fibers were mixed with polyester resin under pressure in a metallic mold, and cured at room temperature for 24 hours. Standard samples were prepared up to $30 \%$ by volume of Fique fibers aligned along its entire length, these specimens were then tested in Izod pendulum impact and the fracture surfaces examined by scanning electron microscopy, SEM. The impact resistance increased substantially with the relative amount of fique fiber reinforcing the composite. This can be attributed to a preferential debonding of the fiber/matrix interface, which contributes to an elevated absorbed energy.
\end{abstract}

Keywords: Composite; Fique; Fiber; Polyester.

1 Graduating in Metallurgical and Materials Engineering, Student, LAMAV, State University of Northern Rio de Janeiro/UENF, Campos dos Goytacazes, Rio de Janeiro, Brazil.

2 Graduating in Mechanical Engineering, Master, Mechanical Engineering Departament, Pontifical Catholic University/PUC, Rio de Janeiro, Rio de Janeiro, Brazil.

3 Graduating in Metallurgical and Materials Engineering, Student, LAMAV, State University of Northern Rio de Janeiro/UENF, Campos dos Goytacazes, Rio de Janeiro, Brazil.

4 Doctor in Materials Engineering, Doctor, Professor, LAMAV, State Univerity of Northern Rio de Janeiro/UENF, Campos dos Goytacazes, Rio de Janeiro, Brazil.

5 Doctor in Materials Engineering, Doctor, Assistant teacher, Science Center in Engineering, Redentor College, Itaperuna, Rio de Janeiro, Brazil.

6 PhD in Material Engineering, Emeritus Profesor, Departament of Materials IME, Rio de Janeiro, Brazill 


\section{INTRODUCTION}

Due to growing concern about the ambient impacts from industrial activities, our society is ever more searching for environmentally friendly materials. In this regard, cellulose-based natural fibers, known as lignocellulosic fibers, become a promising solution. Nowadays, they are being considered as a substitute for synthetic fibers, such as glass fiber, used by the industry on a large scale [1-13]. In fact, others benefits are motivating the substitution of natural fibers for glass fiber in polymer composites[14],such as technical, economical and societal advantages[15].

The use of composites reinforced with natural fibers is a reflection of the concerns with environmental issues such as pollution caused by waste that is not biodegradable or cannot be incinerated and climate change due to $\mathrm{CO} 2$ emissions associated with the processes of intensive energy [16-18]. Additionally, it is worth also remembering that these fibers come from renewable sources, in addition to being abundant, inexpensive and have a relevant set of mechanical properties [19].

The objective of this study was a preliminary assessment, through tests of Izod impact energy, together with the microstructural characteristics associated with the fracture of polyester matrix composites incorporated with continuous and aligned Fique fibers.[20]

\section{EXPERIMENTAL PROCEDURE}

The basic material used in this work was the fiber extracted from the leaf of Fique plant (Furcraea Andina), Figure I (a), supplied by a producer in Colombia. No treatment was applied on Fique fibers, Figure I (b).
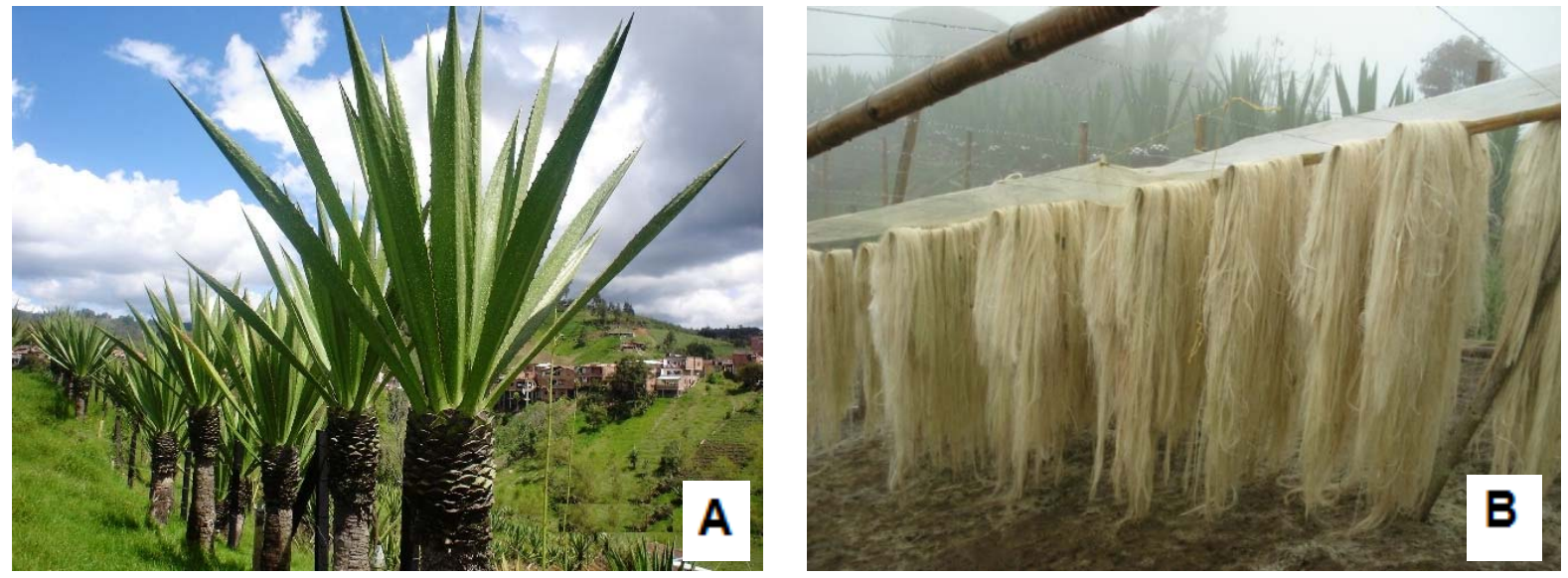

Figure 1. Fique plant (a) and its fibers (b).

The Fique fibers were mixed in amounts of $0,10,20$ and $30 \%$ by volume with unsaturated polyester resin to prepare the composites. Plates of the composites with $10 \mathrm{~mm}$ thickness were fabricated in a rectangular steel mold with dimensions of $152 \mathrm{x}$ $125 \mathrm{~mm}$. The fibers were maintained aligned along the dimension of $125 \mathrm{~mm}$, corresponding to the final length of the test specimens. The still liquid polyester resin, together with $0.5 \%$ catalyst based on methyl ethyl ketone, was poured into the Fique fibers inside the mold. The composite thus formed was allowed to cure for 24 hours at room temperature. The plate of each different composite was then cut according to the direction of fiber alignment in bars measuring $10 \times 125 \times 12.7 \mathrm{~mm}$. These bars were used for preparation of samples for lzod impact test, according to ASTM D256. 
The samples were impact tested in a PANTEC pendulum with Izod configuration. The impact energy was obtained using an $11 \mathrm{~J}$ power hammer for composites with 0,10 , 20 and $30 \%$ of fibers. For each condition, relative to a certain volume fraction of fibers, 12 specimens were used and the results were statistically interpreted.

\section{RESULTS AND DISCUSSION}

Table I shows the results of the values of Izod impact energy with their respective standard deviations for pure polyester and composites with different volume fractions of Fique fiber.

Table 1: Energy Impact Izod for polyester matrix reinforced with banana fibers.

\begin{tabular}{c|c}
\hline Fiber Content $(\%)$ & Impact Energy $(\mathrm{J} / \mathrm{m})$ \\
\hline 0 & $13.00 \pm 2.00$ \\
\hline 10 & $165.70 \pm 29.70$ \\
\hline 20 & $231.10 \pm 35.30$ \\
\hline 30 & $303.91 \pm 42.50$ \\
\hline
\end{tabular}

From the data in Table I, the graph of the energy absorbed in the Izod impact vs. the corresponding volume fraction of Fique fibers in the polyester matrix was plotted, as shown in Figure II. This figure shows a significant increase in the Izod impact energy with the amount of Fique fibers.

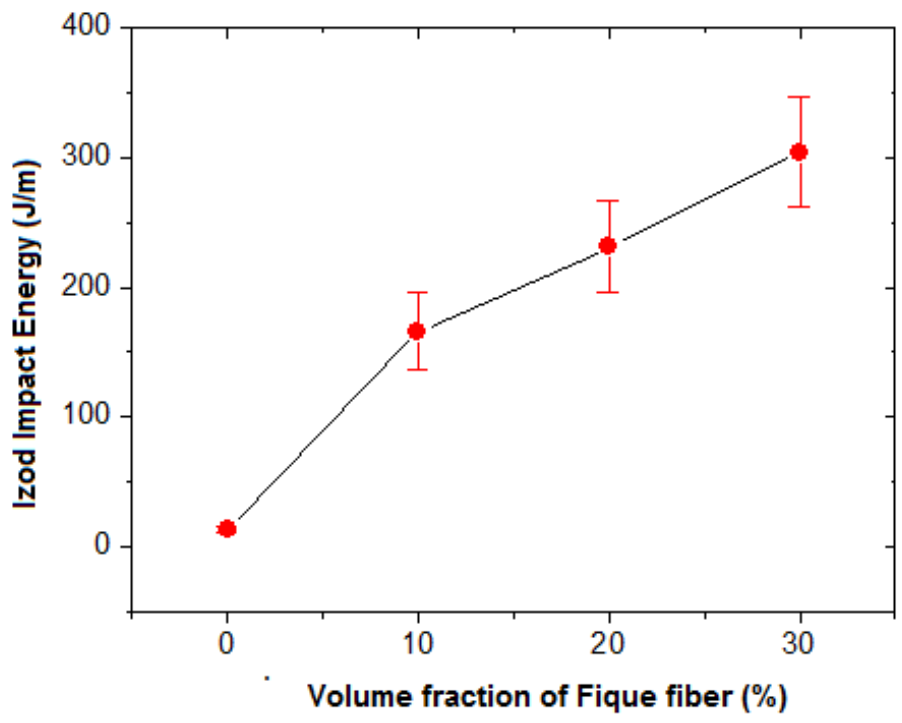

Figure 2: Variation of the Izod impact energy with the amount of fiber in the composites.

This figure displays that the Fique fiber incorporated into the polyester matrix extensively increases the toughness of the composite Izod notch. Values shown are consistent with the results described in the literature for lignocellulosic fibers as well as synthetic fibers. Table II compares Izod impact energy values polymer composites with different lignocellulosic fibers. 
Table 2: Izod notch toughness of polymer composites reinforced with natural fibers.

\begin{tabular}{ccccc}
\hline Composite & Amount of Fiber (\%) & $\begin{array}{c}\text { Izod Impact } \\
\text { Toughness (J/m) }\end{array}$ & Reference \\
\hline Fique/ Polyester & 30 (aligned) & 303.91 & this work \\
Sisal/ Polyester & 30 (aligned) & 2956 & {$[26]$} \\
Ramie/ Polyester & 30 (aligned) & 538 & {$[24]$} \\
Coir/ Polyester & 30 (aligned) & 121 & {$[25]$} \\
Curaua/ Polyester & 30 (aligned) & 190 & {$[23]$} \\
Coir/ Polypropylene & 30 (short and random) & 46 & {$[23]$} \\
Jute/ Polypropylene & 30 (short and random) & 39 & {$[23]$} \\
Curaua/ Polypropylene & 30 (short and random) & 54 & {$[23]$} \\
Flax/ Polypropylene & 30 (short and random) & 38 & {$[23]$} \\
\hline
\end{tabular}

Figure III shows the macrostructural appearance of broken specimens with different amounts of Fique fibers, from 0 to $30 \%$ in volume. It is important to note that only the pure polyester specimen was completely separated in two parts, which means that the polyester matrix without the addition of Fique fiber is brittle. A non-occurrence of rupture on impact indicates a high toughness of the composite as if the rupture occurred, the absorbed energy would be even higher.

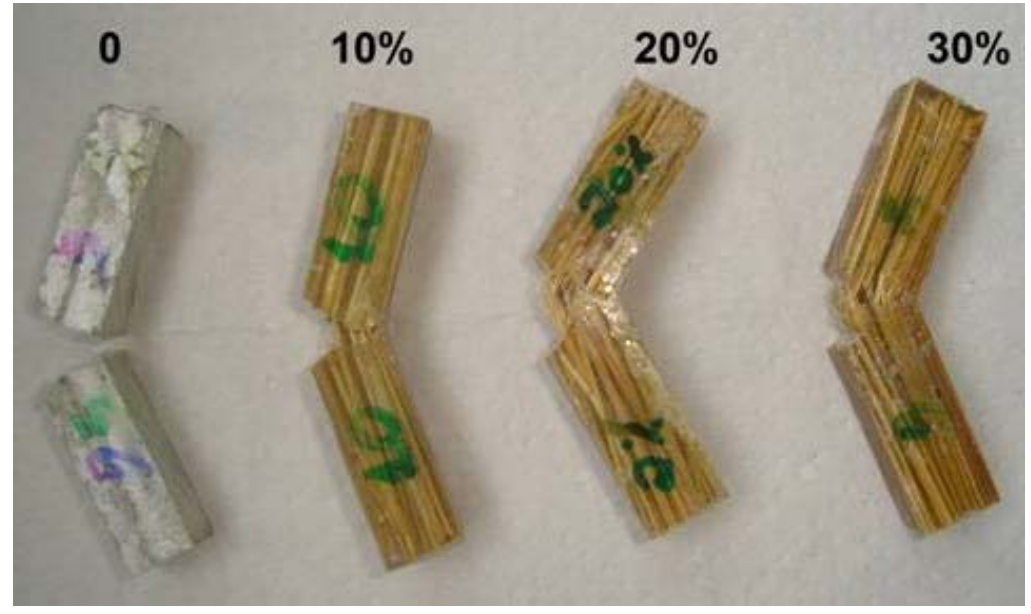

Figure 3: Macrostructural aspects of rupture by Izod Impact composite polyester matrix with different volume fractions of Fique fibers.

For most lignocellulosic fibers, the increase in the Izod impact energy is directly related to the increase in the fiber volume fraction[21]. Other lignocellulosic fibers present the same behavior[22], which is due to the heterogeneous nature of these fibers, causing substantial dispersion in the composites properties. Even considering the error bars, it is possible to interpret the increase of impact energy, as following a linear relationship. When using long fibers for the same proportion, there is a greater area of adhesion between the fiber and the matrix. Fibers embedded in matrix have a greater capacity to absorb the impact and distribute energy throughout its length in a short time interval, consequently, there is less decoupling between the fiber and the matrix. Thus, the fiber in the composite absorbs a large amount of power, leading to an increased impact resistance. 


\section{CONCLUSION}

- The incorporation of Fique fibers in polyester matrix, increases the toughness of the composite, if compared with the pure resin.

- The Izod impact testing fiber in the composite shows that continuous and aligned Fique fibers work with reinforcement in polyester matrix , increasing the ductility linearly.

- Along with the retention of some whole banana fibers upon impact, low interfacial resistance results in greater energy absorbed due to the propagation of cracks in the fiber / matrix interface, allowing the formation of a higher longitudinal fracture area in relation to a transverse fracture, which should occur in the matrix for breaking the fibers.

\section{Acknowledgements}

The authors thank the Brazilian agencies: CNPq, CAPES and FAPERJ.

\section{REFERENCES}

1. A.K. Bledski and J. Gassan: Composites reinforced with cellulose-based fibers. Prog. Polym. Sci, Vol.4 (1999) p.221-274.

2. A.K. Mohanty, M. Misra and G. Hinrichsen: Biofiber, biodegradable polymers and biocomposites: an overview. Macromol. Mat. Eng. Vol. 276/277 (2000) p.1-24.

3. D. Nabi Sahed and J.P. Jong: Natural fiber polymer composites: a revew. Adv. Polym. Technol. Vol. 18(4), (1999) p.351-363.

4. S.J. Eichhorn, C.A. Baillie, N. Zafeiropoulos, L. Y. Mwaikambo, M.P. Ansell and A. Dufresne: Review - Current international research into cellulosic fibers and composites. J. Mat. Sci. Vol. 36 (2002) p. 19-26.

5. A.K. Mohanty, M. Misra and L.T. Drzal: Sustainable bio-composites from renewable resources: opportunities and challenges in the green materials world. J Polym Environ Vol. 10 (2002) p. 19-26.

6. A.N. Netravali and S. Chabba: composites get greener. Mater Today. Vol. 6 (2003) p.2229.

7. J. Crocker: Natural materials innovative natural composites. Mater Technol Vol. 2-3 (2008); p. 174-178.

8. M.J. John and S. Thomas: Biofibers and biocomposites. Carbohydr. Polym. Vol. 71 (2008); p.343-364.

9. Kestur G. Satyanarayana, Gregorio G. C. Arizaga, and Fernando Wypych. Biodegradable composites based on lignocellulosic fibers - An overview. Progress in Polymer Sience. Vol. 34 (2009) p. 982-1021.

10. S.N. Monteiro, F.P.D. Lopes, A.S. Ferreira and D.C.O. Nascimento: Natural fiber polymer matrix composites: cheaper, tougher and environmentally friendly. JOM. Vol. 61 (2009) p. 17-22.

11. S.N. Monteiro, F.P.D. Lopes, A.P. Barbosa, A. B. Bevitori, I.L. Silva and L.L. Costa: Natural Lignocellulosic fibers as engineering materials. Metal. Mater. Trans A, Vol. 42 (2011) p. 2963-2974.

12. S. Kalia, B.S. Kaith and I. Kaurs: Cellulose Fibers: Bio and Nano-Polymer Composites . (New York: Springer, (2011).

13. O. Faruk, A.K. Bledski, H.P. Fink and M. Sain: Biocomposites reinforced with natural fibers: 2000-2010. Progress in Polymer Science. Vol.37 (2012) p.1552-1596.

14. P. Wambua, I. Ivens and I.Verpoest, "Natural fibers: can they replace glass and fiber reinforced plastics?”, Composites Science and Technology, 63 (2003) 1259-1264. 
15. Crocker, J., "Natural materials innovative natural composites". Materials Technology, 2-3 (2008) 174-178.

16. S.N. Monteiro, F.P.D. Lopes, A.S. Ferreira, Nascimento, D.C.O. "Natural fiber polymer matrix composites: cheaper, tougher and environmentally friendly", JOM, v.61, (2009) 17-22.

17. R.C.M.P. Aquino, J.R.M. D'Almeida, S.N. Monteiro, "Flexural Mechanical Porperties of Piassava Fibers (Attalea funifera)-Resin Matrix Composites", Journal of Materials Science Letters, v. 20, (2001) 1017-1019.

18. A.P. Kumar, R.P. Singh, B.D. Sarwade, "Degradability of Composites, Prepared from Ethylene-Propylene Copolymer and Jute Fiber under Accelerated Aging and Biotic Environments", Mat. Chemistry and Physics, v. 92, (2005) 458-469.

19. J. Crocker, "Natural materials innovative natural composites", Materials Technology, n.23, (2008)174-178.

20. S.N. MONTEIRO, R.C.M.P. AQUINO, F.P.D. LOPES, E.A. CARVELHO and J.R.M. D'ALMEIDA, Tenacidade ao entalhe por impacto charpy de compósitos de poliéster reforçados com fibras de piaçava. Rev. Mater., v.11, 2006, p.204-210.

21. Yue, C.Y.; Looi, H.C; Quel, M.Y. (2005) Assessment of Fibre-Matrix Adhesion and Interfacial Properties Using the Pullout Test. Int. J. Adhesion and Adhesives, v. 15, p. 73-80, 1995.

22. Bledzki, A.K.; Gassan, J. (1999) Composites reinforced with cellulose-based fibres. Prog. Polym. Sci, v. 24, p. 221-274.

23. MONTEIRO, S.N.; FERREIRA, A.S.; LOPES, F.P.D. Izod impact energy of polyester matrix composites reinforced with aligned curaua fibers. In: Mineral, Metals \& Materials Characterization Symposium - TMS Conference, San Francisco, EUA, March 2009. p. 1-8.

24. MONTEIRO, S.N.; MARGEM, F.M.; SANTOS JR., L.F.L.; Ensaios de impacto Izod em compósitos poliméricos reforçados com fibras de rami. In: $18^{\circ}$ Congresso Brasileiro de Engenharia e Ciencia dos Materiais, CBECIMAT 2008, Porto de Galinhas, PE, November, 2008, p. 1-12.

25. MONTEIRO, S.N.; COSTA, L.L.; LOPES, F.P.D.; TERRONES, L.A.H. Characterization of the impact resistance of coir fiber reinforced polyester composites, In: Mineral, Metals \& Materials Characterization Symposium - TMS Conference, New Orleans, LA, USA, March, 2008, p. 1-6.

26. MONTEIRO, S.N.; PEREIRA, A.C.; INÁCIO, W. P.; Izod impact energy of polyester matrix composites reinforced with aligned sisal fibers. In: Associação Brasileira de Metalurgia e Materiais - ABM, São Paulo, SP, Julho, 2011, p. 1-12. 